\title{
Gibberellic acid, paclobutrazol, fluoridone, abscisic acid affecting flowering and fruit set of coffee ${ }^{1}$
}

\author{
Carlos A. Flores ${ }^{2}$, Winston De la Torre ${ }^{3}$, Miguel Monroig ${ }^{4}$ \\ and Wigmar González ${ }^{2}$
}

J. Agric. Univ. P.R. 89(3-4):159-168 (2005)

\begin{abstract}
Applications of gibberellic acid (GA), paclobutrazol and gibberellic acid (Paclo/GA), fluoridone and gibberellic acid (FL/GA), and abscisic acid (ABA) were made to synchronize flowering in coffee trees (Coffea arabica L.). Overall growth of trees and branches was not affected by the treatments. Production of new leaves was not affected by the treatments. However, the Paclo/GA treatment tended to increase the production of secondary branches. Flower bud production was affected by the ABA treatment during the first three weeks, showing an initial reduction in number and a late development of buds. Plants receiving the GA treatment produced more flowers during the first week of evaluation as well as a higher number and greater weight of mature fruits during the first week of harvesting.
\end{abstract}

Key words: growth regulators, Coffea arabica, flowering, coffee trees

\section{RESUMEN}

Ácido giberélico, paclobutrazol, fluoridone, ácido abscísico afectan la sincronización de la floración del cafeto

Se realizaron aplicaciones de ácido giberélico (GA), paclobutrazol y ácido giberélico (Paclo/GA), fluoridone y ácido giberélico (FL/GA), y ácido abscísico (ABA) con el propósito de sincronizar la floración del cafeto (Coffea arabica L.). Ninguno de los tratamientos afectó el crecimiento del árbol ni de las ramas. Los tratamientos no afectaron significativamente la producción de hojas nuevas; sin embargo, se observó una tendencia en el tratamiento con Paclo/GA a incrementar el número de ramas secundarias. La producción de yemas florales se afectó con el tratamiento de ABA durante las primeras tres semanas, mostrando una reducción inicial en el número de yemas y un comportamiento tardío en su desarrollo. El tratamiento de GA resultó en una mayor cantidad de flores durante la primera semana de evaluación y un mayor número y peso de frutas maduras durante el primer mes de cosecha.

Palabras clave: reguladores de crecimiento, Coffea arabica, florecida, cafetos

${ }^{1}$ Manuscript submitted to Editorial Board 1 July 2003.

${ }^{2}$ Assistant Researcher, Agricultural Experiment Station, Department of Horticulture.

${ }^{3}$ Professor, Department of Agronomy and Soils.

${ }^{4}$ Extension Specialist, Department of Horticulture. 


\section{INTRODUCTION}

In Puerto Rico coffee (Coffea arabica L.) flowering usually occurs from January to March. Harvesting is currently done by hand. Because of coffee's flowering pattern, and because of the extended fruit- ripening period, which usually takes four to five months, multiple handharvests of fully ripe fruits are required to obtain good quality fruits. Scarcity of labor to harvest the fruits is one of the most common problems in Puerto Rico and other countries. Because of the extended harvesting period, different strategies have been explored to achieve uniform fruit development and ripening (Alvim, 1958; Cannell, 1971; Crisosto et al., 1990; Mes, 1957a; Schuch and Fuchigami, 1988).

Since coffee is a photoperiodic plant (Cannell, 1972; Kumar, 1979; Mes, 1957b; Piringer and Borthwick, 1955), flower buds are induced during the short days of winter and become dormant after reaching 4 to $6 \mathrm{~mm}$ in length (Mes, 1957a; Schuch and Fuchigami, 1988). Watering during the winter is considered necessary to promote normal flower development (Browning, 1975; Dean, 1939; Mathew and Chokkana, 1961; Schuch, 1992). Normally, after dormancy is broken by short rains from January to March, development of flower buds and anthesis occurs within eight to 12 days (Alvim, 1958; Mes, 1957b). A considerable number of flower buds remain dormant possibly because of the lack of endogenous gibberellins (Alvim, 1958; Browning, 1975; Opile, 1977) or water stress (Alvim, 1960; Browning, 1975; Crisosto, 1990) or by not reaching enough development to become dormant before release by water uptake (Kumar, 1979; Opile, 1977).

Studies reveal that trees which experienced leaf water potential (WP) less than -2.65 $\mathrm{MPa}$, and flower bud WP of about $-4.0 \mathrm{MPa}$ bloomed within nine days after irrigation (Schuch, 1992). It has also been established that gibberellins partially compensate for insufficient water stress to initiate anthesis (Van der Veen, 1968). Studies have been conducted to determine whether the effect of gibberellins on flowering depends on the stage of floral bud development at the time of application and its relation with high levels of ABA and low levels of free GA (Van der Veen, 1968). Gibberellins are defined as a class of related plant hormones that stimulate growth of the stem and leaves, trigger the germination of the seed and the breaking of bud dormancy, and stimulate fruit development along with auxins. Exogenous applications of gibberellins at $100 \mathrm{mg} / \mathrm{L}$ have been successfully used to promote earlier flowering and subsequent synchronization of fruit ripening (Lang, 1970; Post, 1943).

On the other hand, the phytohormone abscisic acid (ABA) plays an antagonistic role in the physiological process in all higher plants. Usually this hormone inhibits plant growth and works against gibberellins 
in the development of the bud and seed dormancy. ABA reverses the effect of growth-stimulating hormones (auxin, gibberellins, cytokinin) in several tissues (Zeevaart, 1999a). Manipulation of ABA and metabolite levels has been described as a promising means to improve productivity, performance and plant architecture (Zeevaart, 1999b; Cutler and Krochko, 1999). ABA has a role in ameliorating water stress and dormancy-inducing hormonal and other physiological effects in plants (Creelman, 1989). ABA levels increase dramatically during water stress, which coincides with the dry winter period in Puerto Rico. This period is necessary to induce flower bud development in coffee trees. The ABA biosynthesis pathway involves the formation of a 9-cis-epoxycarotenoid precursor. Oxidative cleavege then results in the formation of xanthoxine, which is subsequently converted to ABA (Taylor, 2000).

Whether xanthoxine is an intermediate of the ABA biosynthesis or an independent product remains unknown (Sengbusch, 1999). Both $\mathrm{ABA}$ and xanthoxine are terpene derivates (carotenoids). The better known pathway for ABA biosynthesis is the degradation of xanthophyll products (especially violaxanthine) from a $\mathrm{C}_{15}$ precursor using a separate pathway independent of the carotenoid/xanthophylls metabolism (Sengbusch, 1999).

Reduction in ABA levels was evaluated by the use of the aquatic herbicide fluoridone, (1-methyl-3-phenyl-5-[3-(trifluromethyl) phenyl]$4(1 \mathrm{H})$ pyridinone), known commercially as Sonar ${ }^{\mathrm{TM}}$. Its use in manipulation of flowering in coffee has not been tested. Its mode of action is inhibiting the carotenoid biosynthesis (Sandmann et al., 1985), known as one of the alternate routes of ABA biosynthesis.

The overall objective of this study was to explore strategies to concentrate flowering in coffee by shortening the time period between floral bud initiation and anthesis. A phenological approach to evaluate coffee flowering is described and used to compare strategies.

\section{MATERIALS AND METHODS}

The experiment was conducted on three-year-old coffee trees (Coffea arabica L. cv. Caturra) growing at the Agricultural Experiment Station in Adjuntas, Puerto Rico. This station is located at $18.11^{\circ}$ latitude North and $66.48^{\circ}$ longitude West at an elevation of 588 meters above sea level. Annual average precipitation is $189.23 \mathrm{~cm}$ and average temperature is $22.2^{\circ} \mathrm{C}$.

Planting distance was $3.0 \times 1.2 \mathrm{~m}$ and the average height of trees was $109 \mathrm{~cm}$. The experiment was arranged in a randomized complete block design with five replications and three trees per replication. Trees were selected for uniform shape with one orthotropic shoot which produced the plagiotropic branches. Four lateral branches at the mid- 
dle of each treatment tree were selected and tagged. This was the area where most flowers developed.

There were five treatments: I-Aqueous solution of $200 \mathrm{mg} / \mathrm{L} \mathrm{GA}$ (Sigma, St. Louis) ${ }^{5}$, dissolved in ethanol, then diluted with distilled water, applied in one application in January; II-Aqueous solution of 200 $\mathrm{mg} / \mathrm{L}$ Paclo (Bonzi ${ }^{\circledR}$, Uniroyal Chemical) sprayed in January, followed by a second spray 15 days later of $200 \mathrm{mg} / \mathrm{L}$ GA in February; III-Aqueous solution of 100 micromolar abscisic acid (ABA) sprayed in January and February 15 days later; IV-Aqueous solution of $0.50 \mathrm{mg} / \mathrm{L}$ fluoridone (Sonar ${ }^{\circledR}$ ELANCO) in January and a second spraying of $200 \mathrm{mg} /$ L GA in February, 15 days later; V-Control trees were sprayed with a solution of $10 \mathrm{ml} / 3.8 \mathrm{~L}$ surfactant Tween $20^{\circledR}$ and distilled water. All solutions included $10 \mathrm{ml} / 3.8 \mathrm{~L}$ surfactant Tween $20^{\circledR}$ and distilled water. Each tree was protected during application to avoid risk of treatment contamination by the wind. Each tree received a total of $250 \mathrm{ml}$ of the respective treatment from a 7.57-L capacity hand sprayer.

Treatment evaluation was divided into two phases: Phase I consisted of an evaluation of the period from floral initiation (candle stage) to fruit set. The number of flower buds, flowers at anthesis, leaves and fruit set were recorded at seven-day intervals from January to April 1993. Branch length and tree growth was recorded at the same time. Phase II consisted of the fruit harvesting period from initiation of ripening, (August 1993) to the end of the harvesting period (December 1993). In this phase mature ripe fruits were collected by hand picking at seven-day intervals. Tagged branches and total tree production was recorded during the evaluation period; only the ripened fruits were collected. Experimental plots were treated as a commercial plantation using all agronomic and cultural practices recommended for the production of coffee (Agricultural Experiment Station, 1984). Analysis of variance and Duncan's multiple range test $(\mathrm{P}=0.05)$ were used to compare the treatment results within each week of the experiment and to compare coffee production.

\section{RESULTS AND DISCUSSION}

\section{Phase I. Evaluation of Period from Bud Formation to Fruit Set}

There were no significant differences in tree height or branch length among treatments. The average weekly branch elongation in all treatments was $0.96 \mathrm{~cm}$. Tree height increased at a similar rate (results not

\footnotetext{
${ }^{5}$ Company and trade names in this publication are used only to provide specific information. Mention of a trade name does not constitute a warranty of equipment or material by the Agricultural Experiment Station of the University of Puerto Rico, nor is this mention a statement of preference over other equipment or materials.
} 
shown). This finding is comparable to results reported in other studies, where no increase in branch length with a single application of $100 \mathrm{mg} / \mathrm{L}$ $\mathrm{GA}_{3}$ was found (Cannell, 1971). During the first four weeks of evaluation, the Paclo/GA treatment produced fewer leaves than did the GA or FL/GA treatments (Table 1). The control did not differ from the treatments.

Flower bud production was reduced with the ABA treatment during the first three weeks of evaluation when compared with that of the control (Table 1). GA treatment was lower in flower bud production compared with that of the control after the sixth, seventh, and eighth weeks of evaluation. This finding might suggest a tendency of GA treatment to concentrate flower bud production in a short period of time (first five weeks), whereas the ABA treatment delayed the response to a late bud production by acting as a retardant of the normal process (Table 1). The largest number of flowers occurred during the first and fourth weeks of evaluation (Table 1). During the first week, GA treatment showed a higher number of flowers than any of the other treatments. No other differences were observed for this variable during the evaluation period.

A higher fruit set $(\mathrm{P}<0.05)$ was observed in GA treatment during the second, third and fourth weeks of evaluation compared to that of all treatments except for the FL/GA treatment at the fourth week (Table 1).

\section{Phase II. Evaluation of Period from Fruit Set to Harvest}

Gibberellic acid treatment produced a greater amount of coffee berries $(\mathrm{P}<0.05)$ collected from selected branches during the first week of evaluation. During that week coffee berry production with the GA treatment was $297 \%$ higher than that of the control (Table 2). Few other differences were found during the evaluation period (16 weeks) among treatments. Similar results were observed when total tree production was evaluated (Table 2). The GA and FL/GA treatments resulted in more coffee production than the Paclo/GA, ABA and control treatments during the first week of harvesting.

Our results suggest that the target of growth regulators tested in this study is a physiological mechanism not related to tree growth and branch length during the flowering season. The effect of these growth regulators on leaf production remains uncertain because results of applications of Paclo/GA differed from those of GA and FL/GA but did not differ from the control and those with application of ABA. Visual observations were not quantified, but apparently there was a higher production of secondary and tertiary branches in the Paclo/GA treatment. More studies are required on this subject. To our knowledge, no similar effects have been reported in the literature. 


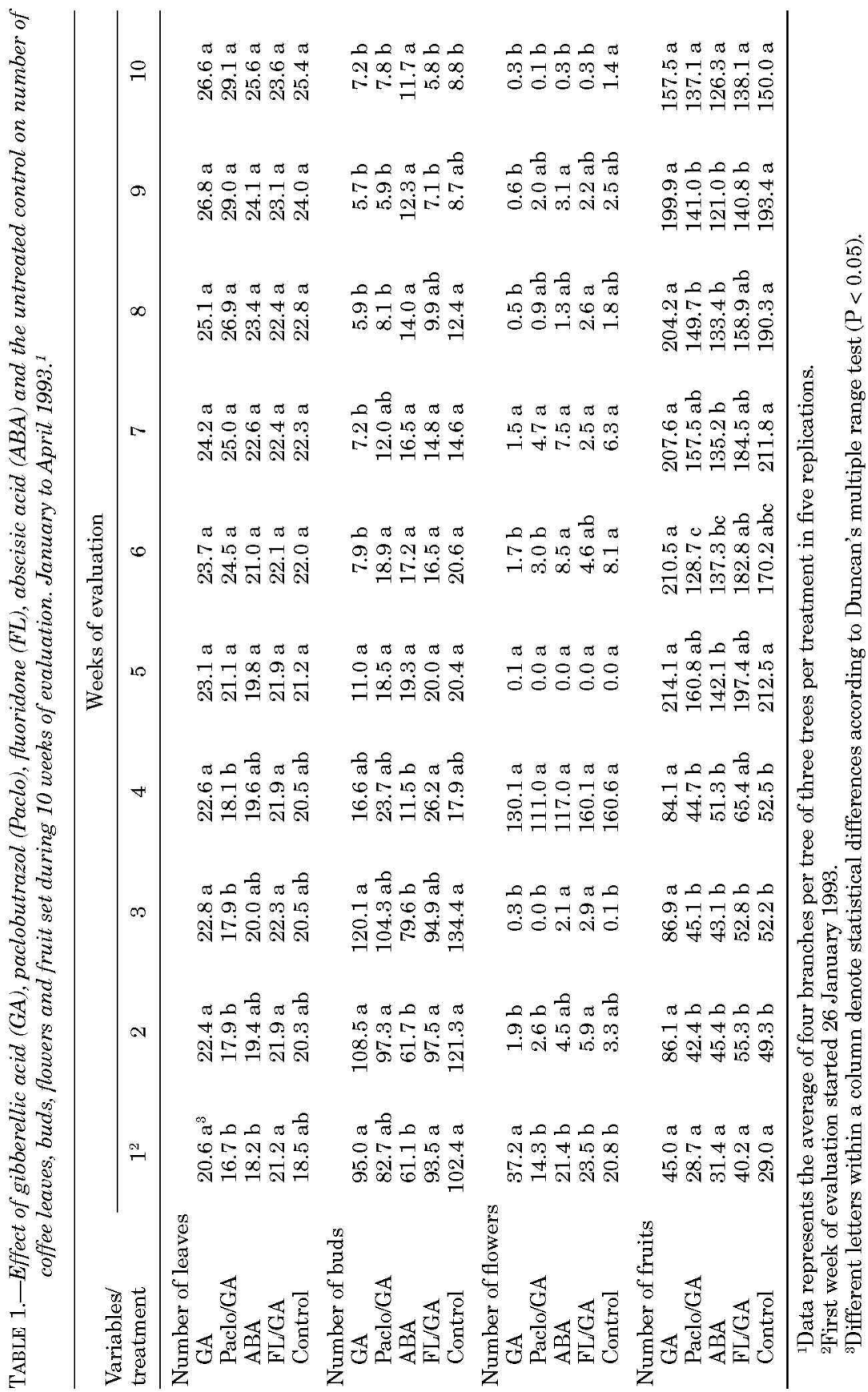


TABLE 2.-Effect of gibberellic acid (GA), paclobutrazol (Paclo), fluoridone (FL), abscisic acid (ABA) and the untreated control on total fruit production in selected coffee branches during 16 weeks of evaluation. September to December $1993 .{ }^{1}$

\begin{tabular}{|c|c|c|c|c|c|c|c|c|c|c|c|c|c|c|c|c|}
\hline \multirow{2}{*}{$\begin{array}{l}\text { Variables/ } \\
\text { treatment }\end{array}$} & \multicolumn{16}{|c|}{ Weeks of evaluation } \\
\hline & $1^{2}$ & 2 & 3 & 4 & 5 & 6 & 7 & 8 & 9 & 10 & 11 & 12 & 13 & 14 & 15 & 16 \\
\hline \multicolumn{17}{|c|}{ Number of fruits in selected coffee branches (g) } \\
\hline GA & $441.8 \mathrm{a}$ & $72.8 \mathrm{a}$ & $222.8 \mathrm{a}$ & $222.4 \mathrm{a}$ & $215.6 \mathrm{a}$ & $184.6 \mathrm{a}$ & $123.6 \mathrm{a}$ & $165.2 \mathrm{a}$ & $436.4 \mathrm{ab}$ & $245.2 \mathrm{a}$ & $124.0 \mathrm{~b}$ & $43.0 \mathrm{a}$ & $14.0 \mathrm{a}$ & $12.0 \mathrm{a}$ & $2.8 \mathrm{a}$ & $2.4 \mathrm{a}$ \\
\hline Paclo/GA & $153.0 \mathrm{~b}$ & $48.8 \mathrm{a}$ & $151.6 \mathrm{a}$ & $131.8 \mathrm{a}$ & $137.8 \mathrm{a}$ & $86.2 \mathrm{a}$ & $86.4 \mathrm{a}$ & $126.4 \mathrm{a}$ & $268.0 \mathrm{ab}$ & $181.2 \mathrm{a}$ & $130.8 \mathrm{~b}$ & $58.8 \mathrm{a}$ & $20.4 \mathrm{a}$ & $18.4 \mathrm{a}$ & $6.2 \mathrm{a}$ & $8.8 \mathrm{a}$ \\
\hline ABA & $156.4 \mathrm{~b}$ & $46.8 \mathrm{a}$ & $115.8 \mathrm{a}$ & a $133.2 \mathrm{a}$ & $156.2 \mathrm{a}$ & $156.6 \mathrm{a}$ & a $103.4 \mathrm{a}$ & $106.8 \mathrm{a}$ & $400.4 \mathrm{ab}$ & $246.0 \mathrm{a}$ & $255.2 \mathrm{a}$ & $84.8 \mathrm{a}$ & $26.4 \mathrm{a}$ & $16.4 \mathrm{a}$ & $13.4 \mathrm{a}$ & $11.2 \mathrm{a}$ \\
\hline FL/GA & $233.2 \mathrm{~b}$ & $68.4 \mathrm{a}$ & $178.4 \mathrm{a}$ & a $145.2 \mathrm{a}$ & a $201.8 \mathrm{a}$ & $164.6 \mathrm{a}$ & a $111.0 \mathrm{a}$ & $80.0 \mathrm{a}$ & $232.4 \mathrm{~b}$ & $134.0 \mathrm{a}$ & $101.6 \mathrm{~b}$ & $54.0 \mathrm{a}$ & $15.6 \mathrm{a}$ & $14.4 \mathrm{a}$ & $7.4 \mathrm{a}$ & $6.0 \mathrm{a}$ \\
\hline Control & $148.6 \mathrm{~b}$ & $38.4 \mathrm{a}$ & $133.4 \mathrm{a}$ & a $181.2 \mathrm{a}$ & $154.6 \mathrm{a}$ & $124.0 \mathrm{a}$ & a $154.8 \mathrm{a}$ & $225.2 \mathrm{a}$ & $532.4 \mathrm{a}$ & $268.8 \mathrm{a}$ & $199.6 \mathrm{ab}$ & $76.0 \mathrm{a}$ & $25.2 \mathrm{a}$ & $26.8 \mathrm{a}$ & $12.2 \mathrm{a}$ & $8.0 \mathrm{a}$ \\
\hline \multicolumn{17}{|c|}{ Total fruit production in coffee trees $(\mathrm{kg})$} \\
\hline GA & $12.83 \mathrm{a}$ & $2.41 \mathrm{a}$ & $7.85 \mathrm{a}$ & $8.10 \mathrm{a}$ & $8.74 \mathrm{a}$ & $9.23 \mathrm{a}$ & $7.32 \mathrm{a}$ & $8.75 \mathrm{a}$ & $31.95 \mathrm{a}$ & $20.66 \mathrm{a}$ & $13.96 \mathrm{a}$ & $4.91 \mathrm{a}$ & $1.68 \mathrm{~b}$ & $0.96 \mathrm{a}$ & $0.56 \mathrm{a}$ & $0.36 \mathrm{a}$ \\
\hline $\mathrm{Paclo} / \mathrm{GA}$ & $4.86 \mathrm{~b}$ & $1.50 \mathrm{a}$ & $4.77 \mathrm{a}$ & $4.23 \mathrm{a}$ & $4.59 \mathrm{a}$ & $3.91 \mathrm{~b}$ & $4.45 \mathrm{a}$ & $6.98 \mathrm{a}$ & $20.54 \mathrm{a}$ & $12.82 \mathrm{a}$ & $11.19 \mathrm{a}$ & $5.62 \mathrm{a}$ & $2.46 \mathrm{ab}$ & $1.20 \mathrm{a}$ & $1.31 \mathrm{a}$ & $0.59 \mathrm{a}$ \\
\hline ABA & $6.53 \mathrm{~b}$ & $1.34 \mathrm{a}$ & $4.79 \mathrm{a}$ & $4.36 \mathrm{a}$ & $5.07 \mathrm{a}$ & $6.46 \mathrm{ab}$ & b $5.93 \mathrm{a}$ & $5.25 \mathrm{a}$ & $21.96 \mathrm{a}$ & $17.69 \mathrm{a}$ & $22.61 \mathrm{a}$ & $11.02 \mathrm{a}$ & $4.23 \mathrm{ab}$ & $2.06 \mathrm{a}$ & $1.84 \mathrm{a}$ & $1.08 \mathrm{a}$ \\
\hline $\mathrm{FL} / \mathrm{GA}$ & $9.29 \mathrm{ab}$ & $2.18 \mathrm{a}$ & $7.95 \mathrm{a}$ & $6.27 \mathrm{a}$ & $7.97 \mathrm{a}$ & $7.91 \mathrm{ab}$ & b $7.45 \mathrm{a}$ & $7.56 \mathrm{a}$ & $24.00 \mathrm{a}$ & $20.50 \mathrm{a}$ & $20.59 \mathrm{a}$ & $13.90 \mathrm{a}$ & $3.81 \mathrm{ab}$ & $3.99 \mathrm{a}$ & $1.97 \mathrm{a}$ & $1.03 \mathrm{a}$ \\
\hline Control & $5.08 \mathrm{~b}$ & $0.94 \mathrm{a}$ & $4.55 \mathrm{a}$ & $6.43 \mathrm{a}$ & $4.97 \mathrm{a}$ & $6.50 \mathrm{ab}$ & b $6.50 \mathrm{a}$ & $8.42 \mathrm{a}$ & $26.28 \mathrm{a}$ & $19.24 \mathrm{a}$ & $15.45 \mathrm{a}$ & $8.92 \mathrm{a}$ & $4.58 \mathrm{a}$ & $2.55 \mathrm{a}$ & $1.77 \mathrm{a}$ & $1.07 \mathrm{a}$ \\
\hline
\end{tabular}

${ }^{1}$ Data represent the average of four branches per tree of three trees per treatment in five replications.

First week of evaluation started 9 September 1993. 
Although ABA treatments produced the fewest fruits among treatments during the second week, ABA resulted in the highest production at the end of the flowering bud development period (ten weeks), thus suggesting a late production or retardant of the flowering period when compared with the other treatments.

Coffee flower buds become dormant after reaching 4 to $6 \mathrm{~mm}$ in length (Mes, 1957a). Two ways of breaking dormancy have been reported, one by water stress which is considered mandatory for normal flowering development (Alvim, 1960), and the other with the application of exogenous GA to stimulate development to anthesis within eight to 12 days (Browning, 1975; Van der Veen, 1968). ABA application showed a reduction in the amount of flower buds initially and also extended the development period much longer than that of the other treatments. Similar results were found in previous studies on breaking off flower bud dormancy with ABA levels that inhibit blossoming, and GA levels that induce anthesis (Browning, 1975).

The GA treatment accelerated or concentrated anthesis during the first week of evaluation. Trees with this treatment had more developed flower buds than trees with the other treatments. No other differences in anthesis were observed after the second week of evaluation, thus suggesting that the flower opening was the result of competition for space, water and nutrients, or by physiological reaction to overload of fruits at this stage of development. This study did not detect any difference in anthesis other than in the GA treatment during the first week of evaluation.

Fruit set was significantly concentrated with GA treatment during the second to fourth week of evaluation. The results of this study are similar to those of Alvim (1958), but also contradict results of another research where no increase in fruit set on trees treated with GA was found (Schuch and Fuchigami, 1988). Ripening and harvesting periods followed a similar pattern to flowering, where GA and Fl/GA treatments presented a tendency to concentrate ripening of fruits in an early and more concentrated period than the other treatments. In the monthly harvesting analysis, GA produced $31.2 \mathrm{~kg}$ or $22.2 \%$ of its total coffee production during the first month whereas the control produced $16.7 \mathrm{~kg}$ or $13.6 \%$ of its total production during the same period. $\mathrm{Fl} / \mathrm{GA}$ was the second highest treatment the first month, with $25.7 \mathrm{~kg}$ or $17.6 \%$ of its total coffee production.

On the basis of these results, coffee flowering can be manipulated by growth regulators. However, a limitation of the use of hormones to synchronize anthesis in coffee plants is that not all flowers buds are at the same stage of maturity at the moment of hormone application. Therefore, several factors might be the focus for further studies. A water 
stress requirement for flower bud formation is one of the factors that must be considered and controlled. A way to accurately measure flower bud water potential (WP) at the critical stages for flowering is needed. During the development of this study, water uptake from rain was the trigger for the application of exogenous growth regulators. Differences among treatments and among trees within the same treatments included types of canopy development, water potential, soil moisture, and tree condition. All of these factors likely affect the size and stages of the floral buds at the time of treatment application. It is highly recommended that in further studies on coffee flowering synchronization the concentration of floral buds be maximized at candle stage or $4.0 \mathrm{~mm}$ stage, in order to make growth regulator applications more effective. At this stage, more buds are receptive and can be released from dormancy simultaneously with exogenous GA. Further studies are needed on the factors that accumulate and maintain the majority of flower buds in the dormant stage instead of releasing them from dormancy.

\section{LITERATURE CITED}

Alvim, P. de T., 1958. Estímulo de floración y fructificación del cafeto por aspersiones con ácido giberélico. Turrialba 8(2):64-72.

Alvim, P. de T., 1960. Moisture stress as a requirement for flowering of coffee. Science 132 (3423):354-355.

Agricultural Experiment Station, 1984. Conjunto Tecnológico para la Producción de Café. Universidad de Puerto Rico. Publicación 103.

Browning, G., 1975. Shoot growth in Coffea arabica L. Response to rainfall when the soil moisture status and gibberellin supply are not limiting. J. Hort. Sci. 50:1-11.

Cannell, M. G. R., 1971. Use of gibberellic acid to change the seasonal fruiting pattern of arabica coffee in Kenya. J. Hort. Sci. 46:298-298.

Cannell, M. G. R., 1972. Photoperiodic response of mature trees of arabica coffee. Turrialba 22(2):198-206.

Creelman, R. A., 1989. Abscisic acid physiology and biosynthesis in higher plants. Physiologia Plantarum Copenhagen 75:131-135.

Crisosto, C. H., R. V. Osgood and L. R. Cid, 1990. Synchronization of fruit ripening in coffee (Coffea arabica L.) with low concentrations of ethephon. USDA, ARS, Hawaiian Sugar Planter's Assoc. 24 pp.

Crisosto, C. H., 1990. Effects of water deficit on flower opening in coffee (Coffea arabica L.). USDA, ARS, Hawaiian Sugar Planter's Assoc. 46 pp.

Cutler A. J. and J. E. Krochko, 1999. Formation and breakdown of ABA. Trends Plant Sci. 4:472-47.

Dean, L. A., 1939. Relationship between rainfall and coffee yield in the Kona district, Hawaii. J. Hort. Research 59(3):217-223.

Kumar, D., 1979. Some aspects of the physiology of Coffea arabica L.: A review. Kenya Coffee 44(519):9-48.

Lang, A., 1970. Gibberellins: structure and metabolism. Ann. Rev. Plant Physiol. 21:35-38.

Mathew, D. K. and P. I. Chokkana, 1961. Studies on the intake of water and nutrients during development of flower buds to blossom in coffee. Indian Coffee 81(11):264-268.

Mes, M. G., 1957a. Estudios sobre la florescencia del Coffea arabica L. II. Interrupción del estado latente de las yemas del café. IBEC Research Institute 14:15-42. 
Mes, M. G., 1957b. Studies on the flowering of Coffea arabica L. The influence of temperature on the initiation and growth of coffee flower buds. Portugalia Acta Biologica 4(A):328-341.

Opile, W. R., 1977. Effects of gibberellic acid on yield of arabica coffee in Kenya. Kenya Coffee 42(501):395-403.

Piringer, A. A. and H. A. Borthwick, 1955. Photoperiodic responses of coffee. Turrialba $5(1-2): 72-77$.

Post, K., 1943. Low temperatures and flower bud development of azaleas. Am. Soc. Hort. Sci. 43:307-310.

Sandmann. G., P. M. Bramley and P. Boger, 1985. New herbicidal inhibitors of carotene biosynthesis. J. Pest. Sci. 10(19):456.

Schuch, U. K. and L. H. Fuchigami, 1988. Effects of gibberellic acid on flowering of coffee. HortSci. 23(3):742-743.

Schuch, U. K., 1992. Flowering, ethylene production and ion leakage of coffee in response to water stress and gibberellic acid. J. Amer. Soc. Hort. Sci. 117(1):158-163.

Sengbusch, P., 1999. Abscisic Acid (ABA). Botany online: Plant hormones. B-online@botanik.uni-hamburg.de

Taylor. I. B., 2000. Control of abscisic acid synthesis. J. Exp. Bot. 51 (350):1563-1574.

Van der Veen, R., 1968. Plant hormones and flowering in coffee. Acta Botanica Neerlandica 17(5): 373-377.

Zeevaart, J. A., 1999a. Biochemistry and Molecular Biology of Plant Hormones. P. J. J. Hooykaas, M. A. K. Hall, and R. Libbenga (ed.), Elsevier, NJ. pp 189-207.

Zeevaart, J. A., 1999b. Physiological actions and hormonal functions. http://www.abscisicacid.com/functions.htm 